\title{
Isolation and Characterization of Phosphate Solublizing Bacteria from Rhizosphere Soil of Rice in Jammu District, India
}

\author{
Renu Gupta $^{1}$, Harkirat Singh ${ }^{1}$, Bharti Sharma ${ }^{2}$ and Susheel Verma ${ }^{2}$ \\ ${ }^{1}$ Division of Soil Science and Agricultural Chemistry, Faculty of Agriculture, SKUAST-J, \\ Chatha, Jammu, India \\ ${ }^{2}$ Centre for Biodiversity Studies, School of Biosciences and Biotechnology, BGSB University, \\ Rajouri-185234, J\&K, India \\ *Corresponding author
}

\section{A B S T R A C T}

Phosphorous is one of the important macronutrient along with nitrogen which limit the growth, development, and yield of the plant. The soluble forms of phosphorus when

Keywords

Phosphorus,

Phosphate-

Solubilizing

Bacteria (PSB),

Isolation,

Biochemical

characterization,

identification

Article Info

Accepted:

20 May 2018

Available Online:

10 June 2018 applied to soil become insoluble through chemical fixation. The Phosphate solublizing bacteria (PSB) plays a very vital role in making soluble phosphorous available to the plants. A study was undertaken in rice growing area of Jammu district, J\&K, to screen the phosphate solubilizing microorganisms from the rhizosphere soil. The soil samples were collected from two rice growing blocks, R. S. Pura and Bishnah using Global Positioning System. The study revealed the presence of three dominant genera. They were identified following Gram staining method and some biochemical tests. Their phosphate solubilizing ability was screened by halozone test on solid agar plate after the incubation at $28{ }^{\circ} \mathrm{C}$. The observations were recorded at $2^{\text {nd }}, 4$ th and 6 th day interval. The microbes showed the formation of clear zones around their colonies on agar plate. The dominant genera were identified as Bacillus, Pseudomonas and Enterobacter on the basis of biochemical test performed on various isolates these were subjected to identification and placed in group I,VIII and IX by referring to the separation outlined in Bergeys manual of systematic bacteriology Thus, it was observed that PSB from the three genera have the ability to reduce the phosphate unavailability by making it available to plants and can be used as biofertilizers in soil because these microorganisms neutralize the soil and release acid in minute quantity during phosphate solubilization.

\section{Introduction}

Phosphorus $(\mathrm{P})$ is an essential element next only to nitrogen that influence plant growth and production throughout the world (Vassileva et al., 1998; Zahran, 1999; Sagervanshi et al., 2012; Sungthongwises et al., 2012). In comparison to macro nutrients, it is the least mobile and available to plants in most soil conditions (El-Azouni 2008). However, some soil microorganisms are able to mineralize and solubilize $\mathrm{P}$ from the organic and inorganic soil pools (Richardson, 2001). Phosphorous plays a major role in the process of photosynthesis, respiration energy storage and transfer, cell enlargement and 
division and other life processes of a plant. Unlike nitrogen, this element is not acquired through biochemical fixation but comes from other sources including chemical fertilizers, animal manures, and plant residues and, native compounds of phosphorus, both organic and inorganic already present in soil to meet plant requirements (Subba Rao, 1982). Nitrogen fixation depends appreciably on the available forms of phosphorous. However, a large portion of soluble inorganic phosphate applied to soil as chemical fertilizer is rapidly immobilized soon after application and becomes unavailable to plants (Yadav and Dadarwal, 1997). Farmers apply phosphorus fertilizers in order to overcome this problem. Therefore, the release of insoluble and fixed forms of phosphorus is an important aspect of increasing soil phosphorus availability. Plant root-associated phosphate solubilizing bacteria (PSB) have been considered as one of the possible alternatives for inorganic phosphate fertilizers for promoting plant growth and yield (Thakuria et al., 2004). In fact, PSB render more phosphates into the soluble form than required for their growth and metabolism by secreting organic acids and enzymes. The interest in PSB has increased due to the prospective use of efficient strains as bioinoculants (biofertilizer) components in organic agriculture, which is emerging as an alternative to chemical inputs in intensive agriculture (Bashan and Holguin, 1998).

The farmers often fail to apply recommended doses of $\mathrm{P}$ fertilizers to the soil either due to non-availability or high cost of phosphatic fertilizers. The phosphate solubilizing bacteria are obiquotous with variation in forms and population in different soils. (Yahya and AlAzawi, 1998). Use of PSB inoculants is one of the strategy to combat the deficiency of phosphorous and meet the demands of expensive fertilizer. The aim of the present research was to isolate and characterize PSB from the rhizosphere soil of rice and to study the microbial properties in rice growing areas of Jammu district.

\section{Materials and Methods}

\section{Soil sampling}

Soil samples were collected from rice rhizosphere at Panicle initiation stage from each rice growing village of R.S.Pura and Bishnah blocks of Jammu district by using GPS(MAGELLAN, MobileMapper). A total of twenty rice grown villages were selected and from each village two samples were collected, one from Basmati-370 and other from Ratna variety through random sampling. Location of sites is presented in Table 1.

\section{Dilution of soil samples}

The sampled rhizosphere soil was mixed thoroughly to make a composite soil sample. $10 \mathrm{gm}$ of soil sample was diluted to $100 \mathrm{ml}$ to make $10^{-1}$ dilution and further serial dilution were prepared to $10^{-8}$ dilution under aseptic conditions.

\section{Isolation of PSBs}

PSB were isolated on Pikovskaya medium (Pikovskaya, 1948) at panicle initiation stage in rhizosphere soil of two rice varieties, Basmati-370 and Ratna.

\section{Microscopic examination and identification by gram staining}

Bacteria were studied for colony and cell morphology following microscopic examination and further identification by gram staining.(Gram,1884).

\section{Biochemical characterization of isolates}

The bacterial isolates at panicle initiation stage in rhizosphere soil of two rice varieties, 
Basmati-370 and Ratna were characterized using biochemical tests viz. Catalase test, Citrate utilization test, Nitrate reduction test and oxidase test.

\section{Quantitative estimation of Phosphate} solubilization

It was done by following the method given by Selvi et al., 2011.

\section{Results and Discussion}

The study area was chosen after taking into consideration the fact that no such previous work was undertaken on the rice varieties being cultivated there. Since this area in Jammu Division of Jammu and Kashmir State is famous for best quality of Basmati Rice, therefore, the present study holds lot of significance.

\section{Colony morphology of P-solubilising bacteria}

Colonies of all the PSB isolates were round, small, had flat elevation, smooth surface and white in color (Table. 2).

\section{Characteristics of $\mathbf{P}$-soulbilizing bacteria}

An appraisal of data presented in Table. 3 and 4 revealed that $\mathrm{P}$-solubilising bacteria isolated from rhizosphere soils of rice were rod shaped, gram negative and gram positive types. Biochemical tests (Catalase, Nitrate reduction, Citrate utilization and Oxidase test) performed showed positive results except few of them were negative. Majority of Psolubilising bacteria isolated from rhizosphere soil of Basmati-370 were gram negative but the few mixed population isolates were having gram negative as well as gram positive bacteria (Table. 3 ).

\section{Quantitative estimation of Phosphate solubilization}

Maximum amount of phosphate solubilization occurred on sixth day of experiment accompanied with its responsible organisms of genus Bacillus (2.52 $\mathrm{mg} /$ litre) followed by Pseudomonas (2.34 $\mathrm{mg} / \mathrm{litre}) \quad$ and Enterobacter (2.02 mg/litre) in group IX. Besides this, fourth day experiment showed the phosphate solubilization efficiency range from 0.35 to $2.50(\mathrm{mg} / 50 \mathrm{ml})$ in Bacillus as compared to uninoculated conditions respectively in rhizosphere soil. Similar effect was observed initially, second day of experiment. The sets of experiment with two days interval denote the comparatively phosphate solubilization effectively takes place in sixth day with bacteria belonging to genus Bacillus as compared to bacteria from genus Pseudomonas. (Table. 5).

Table.5 Quantitative estimation of Phosphate solubilization in Pikovskaya;s medium

\begin{tabular}{|l|l|l|l|}
\hline \multirow{2}{*}{ Microorganism } & \multicolumn{3}{|l|}{ A vailable phosphate(mg/50ml) } \\
\cline { 2 - 4 } & $2^{\text {nd }}$ day & $4^{\text {th }}$ day & $6^{\text {th }}$ day \\
\hline Uninoculated & 0.36 & 0.35 & 0.35 \\
\hline Genus Bacillus & 0.75 & 2.50 & 2.52 \\
\hline Genus Pseudomonas & 0.50 & 2.35 & 2.34 \\
\hline Genus Enterobacter & 0.42 & 1.86 & 2.02 \\
\hline
\end{tabular}


Table.1 Collection sites of rhizosphere soil samples

\begin{tabular}{|c|c|c|c|}
\hline S. No. & Village & Block & GPS Location \\
\hline 1. & Tinda & RS Pura & $32^{\circ} 37^{\prime} 40.662^{\prime \prime N ~} 74^{\circ} 47^{\prime 2} 23.310^{\prime E}$ \\
\hline 2. & Rattian & RS Pura & $32^{\circ} 37^{\prime} 11.850^{\prime \prime} \mathrm{N} 74^{\circ} 47^{\prime} 09.342^{\prime \prime E}$ \\
\hline 3. & Kir Pind & RS Pura & $32^{\circ} 37^{\prime} 11.568^{\prime \prime N} 74^{\circ} 47^{\prime} 09.048^{\prime \prime E}$ \\
\hline 4. & Mahlawal & RS Pura & $32^{\circ} 37^{\prime} 01.434^{\prime \prime N} 74^{\circ} 46^{\prime} 50.622^{\prime E}$ \\
\hline 5. & Tanda & RS Pura & $32^{\circ} 36^{\prime} 46.944^{\prime \prime N ~} 74^{\circ} 46^{\prime} 27.630^{\prime \prime E}$ \\
\hline 6. & Kotli Shah & RS Pura & $32^{\circ} 36^{\prime} 56.796^{\prime N} 74^{\circ} 46^{\prime} 06.198^{\prime E}$ \\
\hline 7. & Mahlawal & RS Pura & $32^{\circ} 37^{\prime} 03.300^{\prime \prime N} 74^{\circ} 45^{\prime} 52.020^{\prime \prime} \mathrm{E}$ \\
\hline 8. & Tikrian & RS Pura & $32^{\circ} 37^{\prime} 19.884^{\prime \prime N} 74^{\circ} 44^{\prime} 43.182^{\prime \prime E}$ \\
\hline 9. & Banota & RS Pura & $32^{\circ} 37^{\prime} 19.734^{\prime \prime N} 74^{\circ} 44^{\prime} 41.988^{\prime E}$ \\
\hline 10. & Langarwal & RS Pura & $32^{\circ} 37^{\prime} 16.992^{\prime \prime N} 74^{\circ} 42^{\prime 2} 27.378^{\prime E}$ \\
\hline 11. & Kulle & Bishnah & $32^{\circ} 37^{\prime} 13.914^{\prime \prime N} 74^{\circ} 50^{\prime} 40.410^{\prime \prime E}$ \\
\hline 12. & Dhinda & Bishnah & $32^{\circ} 37^{\prime} 06.4988^{\prime N} 74^{\circ} 50^{\prime} 48.810^{\prime E}$ \\
\hline 13. & Bishnah Tehsil & Bishnah & $32^{\circ} 366^{\prime} 58.716^{\prime \prime N} 74^{\circ} 50^{\prime} 57.354 " \mathrm{E}$ \\
\hline 14. & Ban Chak & Bishnah & $32^{\circ} 36^{\prime 2} 24.256^{\prime \prime N ~} 74^{\circ} 52^{\prime} 09.522^{\prime \prime E}$ \\
\hline 15. & Pante Di Chubbian & Bishnah & $32^{\circ} 36^{\prime} 05.634^{\prime \prime N} 74^{\circ} 53^{\prime} 13.776^{\prime E}$ \\
\hline 16. & Sorer Tokor & Bishnah & $32^{\circ} 35^{\prime} 47.604^{\prime \prime N} 74^{\circ} 53^{\prime} 34.026 " \mathrm{E}$ \\
\hline 17. & Chubbian & Bishnah & 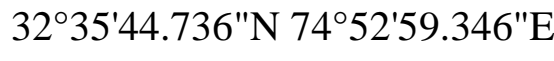 \\
\hline 18. & Chorli & Bishnah & $32^{\circ} 35^{\prime} 56.058^{\prime \prime N} 74^{\circ} 52^{\prime 2} 27.822^{\prime E}$ \\
\hline 19. & Dabbar & Bishnah & $32^{\circ} 35^{\prime} 39.756 " \mathrm{~N} 74^{\circ} 51^{\prime} 46.266^{\prime E}$ \\
\hline 20. & Daali & Bishnah & 32³5'52.932"N 74'50'07.632"E \\
\hline
\end{tabular}


Table.2 Colony Morphology of P-solubilising bacteria in rhizosphere soils in different areas of Jammu District

\begin{tabular}{|l|l|l|l|l|l|l|}
\hline Bacteria & Size & Shape & Elevation & Surface & Consistency & Pigmentation \\
\hline PSB's & Small & Round & Flat & Smooth & Viscous & White \\
\hline
\end{tabular}

Table.3 Isolation and characterization of P-solubilising bacteria from rhizosphere soils of Basmati-370 rice in different areas of Jammu District

\begin{tabular}{|l|l|l|l|l|l|l|l|}
\hline $\begin{array}{l}\text { Sr. } \\
\text { No. }\end{array}$ & Sample & $\begin{array}{l}\text { Gram } \\
\text { staining }\end{array}$ & $\begin{array}{l}\text { Cell } \\
\text { morphology }\end{array}$ & $\begin{array}{l}\text { Catalase } \\
\text { test }\end{array}$ & $\begin{array}{l}\text { Nitrate } \\
\text { reduction } \\
\text { test }\end{array}$ & $\begin{array}{l}\text { Citrate } \\
\text { utilization } \\
\text { test }\end{array}$ & $\begin{array}{l}\text { Oxidase } \\
\text { test }\end{array}$ \\
\hline 1 & R1 & - & Rod shaped & - & + & + & + \\
\hline 2 & R2 & $-\&+$ & Rod shaped & + & + & - & + \\
\hline 3 & R3 & $-\&+$ & Rod shaped & + & + & + & + \\
\hline 4 & R4 & - & Rod shaped & - & + & + & + \\
\hline 5 & R5 & - & Rod shaped & + & + & - & + \\
\hline 6 & R6 & $-\&+$ & Rod shaped & + & + & + & + \\
\hline 7 & R7 & - & Rod shaped & + & + & + & - \\
\hline 8 & R8 & - & Rod shaped & + & + & + & + \\
\hline 9 & R9 & - & Rod shaped & + & + & + & + \\
\hline 10 & R10 & - & Rod shaped & + & - & + & + \\
\hline 11 & B1 & - & Rod shaped & - & + & + & + \\
\hline 12 & B2 & - & Rod shaped & + & + & - & - \\
\hline 13 & B3 & $-\&+$ & Rod shaped & - & + & + & - \\
\hline 14 & B4 & - & Rod shaped & + & + & + & - \\
\hline 15 & B5 & - & Rod shaped & + & + & + & + \\
\hline 16 & B6 & - & Rod shaped & + & + & + & + \\
\hline 17 & B7 & - & Rod shaped & + & + & - & - \\
\hline 18 & B8 & $-\&+$ & Rod shaped & + & + & + & + \\
\hline 19 & B9 & $-\&+$ & Rod shaped & - & + & + & + \\
\hline 20 & B10 & $-\&+$ & Rod shaped & + & + & + & + \\
\hline & & & & + & + & + \\
\hline
\end{tabular}


Table.4 Isolation and characterization of P-solubilising bacteria from rhizosphere soils of Ratna rice in different areas of Jammu District

\begin{tabular}{|l|l|l|l|l|l|l|l|}
\hline Sr. & Sample & $\begin{array}{l}\text { Gram } \\
\text { staining }\end{array}$ & $\begin{array}{l}\text { Cell } \\
\text { morphology }\end{array}$ & $\begin{array}{l}\text { Catalase } \\
\text { test }\end{array}$ & $\begin{array}{l}\text { Nitrate } \\
\text { reduction } \\
\text { test }\end{array}$ & $\begin{array}{l}\text { Citrate } \\
\text { utilization } \\
\text { test }\end{array}$ & $\begin{array}{l}\text { Oxidase } \\
\text { test }\end{array}$ \\
\hline 1 & R1 & $-\&+$ & Rod shaped & + & + & + & + \\
\hline 2 & R2 & $-\&+$ & Rod shaped & + & + & + & + \\
\hline 3 & R3 & $-\&+$ & Rod shaped & - & + & + & + \\
\hline 4 & R4 & $-\&+$ & Rod shaped & + & + & + & + \\
\hline 5 & R5 & $-\&+$ & Rod shaped & + & + & + & + \\
\hline 6 & R6 & $-\&+$ & Rod shaped & + & + & + & + \\
\hline 7 & R7 & $-\&+$ & Rod shaped & + & - & - & + \\
\hline 8 & R8 & $-\&+$ & Rod shaped & + & + & + & + \\
\hline 9 & R9 & $-\&+$ & Rod shaped & + & + & + & - \\
\hline 10 & R10 & $-\&+$ & Rod shaped & + & + & + & + \\
\hline 11 & B1 & $-\&+$ & Rod shaped & + & + & + & + \\
\hline 12 & B2 & $-\&+$ & Rod shaped & - & + & + & - \\
\hline 13 & B3 & $-\&+$ & Rod shaped & + & + & + & + \\
\hline 14 & B4 & $-\&+$ & Rod shaped & + & + & + & - \\
\hline 15 & B5 & $-\&+$ & Rod shaped & + & + & - & + \\
\hline 16 & B6 & $-\&+$ & Rod shaped & + & + & + & + \\
\hline 17 & B7 & $-\&+$ & Rod shaped & + & + & + & + \\
\hline 18 & B8 & $-\&+$ & Rod shaped & + & + & - & + \\
\hline 19 & B9 & $-\&+$ & Rod shaped & - & + & + & + \\
\hline 20 & B10 & $-\&+$ & Rod shaped & + & + & + & + \\
\hline & + & + & + & + \\
\hline
\end{tabular}


The present study revealed the existence of phosphate solubilizing bacteria in the rhizospheric soil of both varieties of rice, Basmati-370 and Ratna being cultivated in R. S. Pura and Bishnah Blocks of Jammu Division of J\&K state. Similar studies have been carried by many other workers from rice as well as other rhizospheric soil of other plants. The PSBs have been isolated from Tea plant from Darjeleeng Hiis (Sharma et al., 2012). They have been isolated from Vigna mungo L. (Qureshi et al., 2012), Festuca arundinacea (Monk et al., 2009), legume plants (Khan et al., 2010)rice grown in acidic soil (Thakuria et al., 2004), rice crop of eastern Uttar Pradesh (Shahi et al., 2009).

In conclusion, present study revealed the existence of Phosphate Solublizing Bacteria in the rhizosphere soils of both Basmati -370 and ratna varieties of rice cultivated in $\mathrm{R}$. S. Pura and Bishna blocks of Jammu division of $\mathrm{J} \& \mathrm{~K}$. These bacteria exhibited difference with respect to Gram property, nitrate reductase, oxidase, citrate utilization and catalase activities. Prominent halo zones were found in case of positive PSB isolates on Pikovskaya's agar. The Isolates exhibited different phosphate solubilization activity as reflected by type of transparent halo zones. Phosphate solubilization effectively took on sixth day with Bacillus than Pseudomonas.

Based on Gram property, bacterial morphology and biochemical tests viz. nitrate reduction, oxidase, citrate utilization and catalase performed on various isolates these were subjected to identification and placed in group I,VIII and IX by referring to the separation outlined in Bergeys Manual of Systematic Bacteriology and confirms the dominance of genus Bacillus, Pseudomonodas, and Enterobacter. The identification at species level will be further undertaken by using appropriate molecular marker.

\section{Acknowledgements}

Authors are thankful to the Head, Division of Soil Sciences and Agricultural Chemistry, SKUAST-J, Jammu and Director, Centre for Biodiversity Studies, BGSBU, Rajouri for providing necessary facilities to carry out this piece of research.

\section{References}

Bashan, Y. and Holguin, G. 1998. Proposal for the division of plant growth-promoting rhizobacteria into two classifications: Biocontrol-PGPB (Plant Growth-Promoting Bacteria) and PGPB. Soil Biology and Biochemistry 30: 1225-1228.

Beck, M. A. and P. A. Sanchez. 1994. Soil phosphorus fraction dynamics during 18 years of cultivation on a Typic Paleudult. Soil Science. 34: 1424 - 14.

EL-Azouni. 2008. Effect of phosphate solubilizing fungi on growth and nutrient uptake of soybean (Glycine max L.) plants. Journal of Applied Science Research 4: $592-598$.

Gram, H.C. 1884. "Über die isolierte Färbung der Schizomyceten in Schnitt- und Trockenpräparaten". Fortschritte der Medizin (in German) 2: 185-189.

Karunai Selvi, B., John Paul, J.A., Ravindran,A.D. and Vijaya, V. 2011. Quantitative estimation of insoluble inorganic phosphate solubilization. International Journal of Science and Nature 2: 292-295.

Khan, M.S., Zaidi, A., Ahmed, M., Oves, M. and Wani, P.A. 2010. Plant growth promotion by phosphate solubilizing fungi- Current Perspective. Archives of Agronomy and Soil Science 56: 73-98.

Kieliszewska-Rokicka B. 2001. Enzymy glebowe i ich znaczenie w badaniach aktywności mikrobiologicznej gleby. In: Drobnoustroje środowiska glebowego; ed.: H. Dahm, A. Pokojska-Burdziej, Toruń, pp. 37-47.

Monk, J., Gerard, E., Young, S., Widdup, K. and O'Callaghan, M. 2009. Isolation and identification of plant growth promoting bacteria associated with tall fescus. 
Proceedings of the New Zealand Grassland Association 71: 211-216.

Pikovskaya, R. I. 1948. Mobilization of phosphorus in soil connection with the vital activity of some microbial species. Microbiologiya 17: 362-370.

Qureshi, M.A., Iqbal, A., Akhtar, N., Shakir, M.A. and Khan, A. 2012. Co-inoculation of phosphate solubilizing bacteria and rhizobia in presence of L-tryptophan for the promotion of mash bean (Vigna mungo L). Soil and Environment 31:47-54.

Richardson, A.E. 2001. Prospects for using soil microorganisms to improve the acquisition of phosphorus by plants. Australian Journal of Plant Physiology 28: 897-906.

Sagervanshi, A., Kumari, P. and Nagee, A. 2012Isolation and characterization of phosphate solublizing bacteria from anand agriculture soil. International Journal of Life Science \& Pharma Resarch 2: L-256L-266.

Shahi S. K., A. K. Rai, M. B. Tyagi, R. P. Sinha and A. Kumar, 2009. Isolation and Characterization of Plant Growth Promoting Rhizobacterea from Rice Crops of Eastern Uttar Pradesh. Journal of Mycology and Plant Pathology 39: 556557.

Sharma B C, R Shubha, A Shaha,2012. Kurthia sps, a noval member of P-Solubilizing bacteria from rhizospheric tea soil of Darjeeling Hills, India. IOSR Journal of Pharmacy and Biological Science 3: 36-37.

Subba Rao, N. S. 1982. Advances in Agricultural Microbiology,. New Delhi: Oxford and IBH

Sungthongwises, K., Boonthaiiwai, C., Matsouka, M., Ohnishi, K. and Tanaka, S. 2012. Isolation of Phosphate Solubilizing Bactera from different filds crop productions. International Journal of Environmental and Rural Development 3: 150-154.

Tarafdar, J.C. and Claassen, N. 1988. Organic phosphorrus compounds as a phosphorus source for higher plants through the activity of phosphatases produced by plant roots and microorganisms. Biology Fertility Soils. 5: 308-312.

Thakuria, D., Talukdar, N. C., Goswami, C., Hazarika, S., Boro, R. C. and Khan, M. R. 2004. Characterization and screening of bacteria from the rhizosphere of rice grown in acidic soils of Assam. Current Science 86: $978-85$.

Vassileva, M., Vassilev, N. and Azcon, R. 1998. Rock phosphate solubilization by Aspergillus niger on olivecake-based medium and its further application in soilplant system. World Journal of Microbiology and Biotechnology. 14: 281284.

Yadav K.S., Dadarwal K.R. 1997. Phosphate solubilization and mobilization through soil microorganism. In: Dadarwal K.R., editor. Biotechnological Approaches in Soil Microorganisms for Sustainable Crop Production. Jodhpur, India: Scientific Publishers, pp. 293-308.

Yahya, I. and Al-Azawi, S. K. 1989. Occurence of phosphate-solubilizing bacteria in some Iraqi soils. Plant and Soil 117:135-141.

Zahran, H. H. 1999. Rhizobium-legume symbiosis and nitrogen fixation under severe conditions and in an arid climate. Molecular Biology Review. 63: 968-989.

\section{How to cite this article:}

Renu Gupta, Harkirat Singh, Bharti Sharma and Susheel Verma. 2018. Isolation and Characterization of Phosphate Solublizing Bacteria from Rhizosphere Soil of Rice in Jammu District, India. Int.J.Curr.Microbiol.App.Sci. 7(06): 2749-2756. doi: https://doi.org/10.20546/ijcmas.2018.706.323 